\title{
TECHNOLOGY USE IN SWEET POTATO PRODUCTION, CONSUMPTION AND UTILIZATION AMONG HOUSEHOLDS IN SOUTHEASTERN NIGERIA
}

\author{
EZEANO, C I. \\ Department of Agricultural Economics and Extension, \\ Rivers State University of Science and Technology Port Harcourt. \\ E-mail: chidykeez@yahoo.com \\ Mobile: 08067505933
}

\begin{abstract}
The study was designed to identify the technology used by households in the production, consumption and utilization of sweet potato in Southeastern Nigeria. Two difference types of structured interview schedules for farmers and consumers were utilized in obtaining information from one hundred and forty-four farmers and seventy - two sweet potato consumers Data were analysed using descriptive statistics. The study revealed that majority (92.4\%) of the farmers used correct spacing (30-50cm apart) and earthening up in sweet potato production, while $90.3 \%$ used cutting off the vine from the base at majority to prevent boring attack by weevils in sweet potato production. Also majority (70.8\%) of the consumers processed sweet potato into snacks/ fried chips while $59.7 \%$ utilized sweet potato for fortification of pounded yam /foofoo and baby's food. The technologies that were highly used by farmers in the production of sweet potato were organic and inorganic fertilizer while the technologies that were highly used by consumers in processing and utilization of sweet potato were processing into snacks /fried chips, flour, dried chips and utilization in the fortification of pounded yam /foofoo, fortification of baby's food and sweetening of beverages (kunu and Burukutu). It was concluded that technologies that are user friendly be developed by research institutes and passed on to state Agricultural Development Programmes (ADPS) for on ward transmission to end-users. The women-in-Agriculture Programme (WIA) of the state level ADPS are strongly recommended to facilitate promotion of processing and utilization of sweet potato technologies among women and multipurpose cooperatives.
\end{abstract}

Keywords: Technology, Sweet potato, utilization, households, southeastern, Nigeria

\section{INTRODUCTION}

Sweet potato (lpomoea batatas $L$ ) is among the worlds most important, versatile, and under exploited food crops, with more than 133 million tones (FAOSTAT, 1997) in annual production. Sweet potato currently ranks as the most important food crop on a fresh-weight basis in developing countries after rice, wheat, maize, and cassava. Among the root and tuber crops, it is the only one that has a positive per capita annual rate of increase in production in sub-Saharan Africa (Bashaasha and Mwanga, 1992). According to Agric News series (1981), yield in formers' farm varies from 6-8 tonnes /ha while under improved management practices yield ranges from 30-37 tonnes / ha. National Root Crops Research Institute (NRCRI), Umudike (1981) estimated that 250, 000ha of land are under Ipomoea batatas production in Nigeria. Food and Agriculture Organization (FAO) estimates of average sweet potato yield of 5 to $8 \mathrm{t} / \mathrm{ha}$ are similar with estimate from surveys conducted by state Agricultural Development Project (ADPs) in Nigeria, which reported yields of popular local varieties from $7 \mathrm{t} / \mathrm{ha}$ in the south eastern zones, 3.5t/ha in the northern zone, and 7 to $8 \mathrm{t} / \mathrm{ha}$ in Plateau and Bauchi states (Tewe, et al, 2003).

Also available data showed that sweet potato production in Nigeria is on the increase (Ezeano, 2006). FAO production books (1960-1984) estimated that from 1971-1972 sweet potato production in Nigeria increased from 1,340 to 3,561 thousand metric tones but 
decreased to 3,000 thousand metric tones in 1973. From 1979 to 1982 production increased from 3, 785 to 3, 850 thousand metric tones. Also FAO production year book $(1989-2001)$, recorded that sweet potato production yield $(\mathrm{kg} / \mathrm{ha})$ and area harvested witnessed a steady increase in Nigeria. It revealed that production increased from 149 thousand metric tones in 1989 to 2, 468 thousand metric tones in 2001 . Sweet potato yield $(\mathrm{kg} / \mathrm{ha})$ increased from 5, 681 to $6,478(\mathrm{~kg} / \mathrm{ha})$ from 1989 - 2001 while area harvested increased from 26 to 381 thousand heaters. FAO food Balance sheets $(1999$ - 2001) for Nigeria revealed that 1,725 thousand metric tones of sweet potato were utilized for food and the total domestic supply was 2,464 thousand metric tones. There seems to be an upward thrust in the trends of sweet potato production and utilization in Nigeria in the recent as a result of the recent sweet potato technologies adopted by farmers. These developments not withstanding, sweet potato is one of the most misunderstood of the major food crops (Ezeano, 2006). It was commonly categorized as "strictly subsistence", "food security" or "famine relief crop" (Scott and Maldonado, 1999). The pertinent questions are; what are the indigenous and improved technologies used by farmers and consumers in the production, consumption and utilization of sweet potato and what is the extent of use of these technologies by farmers and consumers in southeastern Nigeria. The objective of this study was therefore to analyze the technologies used in sweet potato production among households in southeastern Nigeria. Specifically, the study identified the indigenous and improved sweet potato technologies used by households in southeastern Nigeria and the extent of use of these technologies.

\section{METHODOLOGY}

The study was carried out in the Southeast agro-ecological zone of Nigeria which is made up of Abia, Anambra, Akwa - Ibom, Bayelsa, Cross River, Ebonyi, Enugu, Imo and Rivers State. All the sweet potato farmers and consumers in the study area formed the population of the study. Three (3) states namely; Ebonyi, Enugu and Cross River states were purposively selected so as to cut across the entire agronomic and socio-cultural situations in the zone. Four, (4) communities from each of the selected states were purposively selected based on their high potentials in sweet potato production, consumption and utilization (Viz: Cross River-: Bekwara, Bendege, Utugwam and Akamkpa; Ebonyi-: Ishiagu, Nkalagu, Abomega and Noyo -Elike; Enugu-: Ugwuoba, Ihe, Ogbaku and Edem. Simple random sampling technique was used to select twelve (12) farm households and six (6) consumer households from each town who are seriously involved in sweet potato production, consumption and utilization making a total of 144 farm households and 72 consumer households. Thus a total of 216 households involved in sweet potato production, consumption and utilization were sampled for data collection.

Two interview guides ' $\mathrm{A}$ ' and ' $\mathrm{B}$ ' containing both semi-structured and open-ended questions were used for data collection. Instrument ' $A$ ' was administered to sweet potato farmers while instrument ' $\mathrm{B}$ ' was administered to the sweet potato consumers. Variables considered under technologies used by farmers according to Ezeano (2006) included, fertilizer application, improved sweet potato varieties, correct length of vine cuttings (2-5 nodes), correct spacing (30-50cm apart), cutting off vines from the base at maturity to prevent boring attack by weevils, rolling and typing of vines at the base to increase tuber size, harvesting in bits and detopping to encourage more tuber production, use of insecticide /fungicide, herbicide, tractors, oxen, use of sprouts, seeds/ leaf buds, storage in pits, use of compatible inter crops, and stand geometry. Technologies used by consumers included; processing into chips, flour, snacks, starch, noodles, alcohols, medicinal syrup, culture media, utilization in confectionary products like chinchin, fritters, buns, doughnut, strips, bread, queen cake, croquette, beverages (kunu, burukutu) and livestock feeds (Ezeano, 2006). 
Data collected on the technologies used by both farmers and consumers were analysed by use of percentage while data on the extent of use of these technologies were analysed by use of mean scores. A five point Likert- type scale was developed and used to determine the extent of use of the variables by both farmers and consumers. The response options and values assigned were as follows: Very Great Extent $(\mathrm{VGE})=5$ : Great Extent $(\mathrm{GE})=4$, some Extent $(\mathrm{SE})=3$; Low Extent $(\mathrm{LE})=2$; and Very Low Extent $(\mathrm{VLE})=1$. Any technology with mean $>3.0$ was regarded as High Usage while mean $<3.0$ was regarded as low Usage.

\section{RESULTS AND DISCUSSION}

Indigenous and improved technologies used by farmers and consumers in the production, consumption and utilization of sweet potato.

The result in Table 1 showed that majority (92.4\%) of the farmers used correct spacing (30-50cm apart) and earthening- up in sweet potato production, while $90.3 \%$ of the farmers used cutting - off the vine from the base at maturity to prevent boring attack by weevils in their production. Also $89.6 \%$ and $81.3 \%$ of the farmers used rolling and typing of the vine at the base to increase tuber size and organic fertilizer application in sweet potato production respectively. Furthermore $74.3 \%$ and $71.5 \%$ of the farmers used inorganic fertilizer application and correct length of vine cutting (2-5 nodes) respectively in their production. Fifty percent of the farmers used harvesting in bits and detopping to encourage more tuber production in sweet potato production. Ezeano (2006) noted that certain traditional /indigenous practices apart from increasing productivity also suppress pest attack. Talekar (1987) and Ezeano (2006) observed that earthening - up, mulching, early harvest of tubers, deep planting of cuttings, destruction of crop residues, use of weevil-free cuttings, weeding and crop rotation help in the control of sweet potato weevils, (Cylas formicarius).

On the consumption, processing and utilization of sweet potato products, majority (70.8\%) of the consumers indicated that they processed sweet potato into snacks (fried chips). Also $59.7 \%, 58.3 \%, 56.9 \%, 58.3 \%$ and $50.0 \%$ agreed that sweet potato is processed and utilized for fortification of foo-foo / pounded yam, chips, flour, fortification of baby's food, beverages (kuru, Burukutu) respectively. According to Ezeano (2006), the processing and utilization of sweet potato into other products have not received the expected result and attention of consumers, industries and others end - users probably because it is a relatively new technology. In addition to this fact, Tewe et al (2003) opined that sweet potato flour is usually unacceptable for consumption because of its dark colour and extremely sweet taste. To suppress the dark colour and sugary taste in confectionary products, Nnawuchi et al (2002) recommended that in production of buns, doughnut and chin-chin, $40 \%$ sweet potato wheat composite dough product should be used as it was comparable to $100 \%$ wheat dough products, with respect to flavour, colour, texture and overall acceptability.

Table 1: Distribution of respondents according to their use of improved and indigenous sweet potato technologies

Technologies for farmers $(n=144) \quad \%$

1. $\quad$ Correct spacing (30-50cm apart) $\quad 92.4$

2. Earthening - up 92.4

3. Cutting of the vine from the base at maturity

to prevent boring attack by weevils 90.3

4. Rolling and tying of vines at the base to
increase tuber size

5. Organic fertilizer application $\quad 81.3$

6. Inorganic fertilizer application 74.3

7. Correct length of vine cuttings (2-5 nodes) 71.5 
8. Harvesting in bits and detopping to encourage more tuber production

9. $\quad$ Stand geometry (stand erect)

10. Use of seeds $\backslash$ leaf buds for planting

11. Use of compatible intercrop 36.8

12. Use of sprouts for planting 36.8

13. Use of insecticide \fungicide 36.8

14. Storage in pits with ash and dried grass 30.6

15. Use of herbicide (weed control) 26.4

16. Use of Tractors for cultivation 25.0

17. Use of Oxen for cultivation

Technologies for consumers $n=72$ )

\section{Processing into:}

18. Flour

19. Chips 58.3

20. Snacks (fried chips) $\quad 70.8$

21. Starch 3.5

22. Starch to make noodles 4.1

23. Alcohol 1.0

Utilization in the production of:

24 Chin-chin and fritters $\quad 8.3$

25. Buns, doughnut, strips, akara 14.6

26. Bread, queen cake, croquette 10.4

27. Beverages (Kunu, Burukutu) 50.0

28. Livestock feed 14.6

29. Syrup, culture media 1.0

30. Fortification of baby's food $\quad 56.9$

31. Fortification of foo-foo \pounded yam. 59.7

\section{Multiple responses}

\section{Extent of use of indigenous and improved sweet potato technologies by farmers and consumers}

Entries in Table 2 revealed that the following sweet potato technologies with their corresponding mean and standard deviations were highly used by farmers in the study area; organic fertilizer application (mean $=4.1 ; \mathrm{SD}=0.8)$, inorganic fertilizer $($ mean $=4.0 ; \mathrm{SD}=$ $0.9)$, correct length of vine cuttings $(2-5$ nodes $)($ mean $=3.8 ; \mathrm{SD}=1.3)$, correct spacing $(30$ $50 \mathrm{~cm})($ mean $=3.8 ; \mathrm{SD}=1.3)$, earthening up (mean $=3.7 ; \mathrm{SD}=1.3)$, cutting off the vine from the base at maturity to prevent boring attack by weevils (mean $=3.7 ; \mathrm{SD}=1.4$ ), rolling and typing of vines at the base to increase tuber size (mean $=3.6 ; \mathrm{SD}=1.4$ ), harvesting the tubers in bits and detopping to encourage of induce more tuber production (mean $=3.6 ; \mathrm{SD}=$ 1.4) respectively. The low standard deviation (SD) indicated the closeness of the technologies or observations to the respective mean.

In the same vein, the following sweet potato technologies with their corresponding mean and standard deviations were highly used by the consumers, processing into; flour $($ mean $=3.1 ; \mathrm{SD}=1.3)$, chips $($ mean $=3.1 ; \mathrm{SD}=1.6)$, snacks $/$ fried chips $($ mean $=3.7 ; \mathrm{SD}=$ 1.4); utilization in; beverages ( $k$ unu and Burukutu) (mean $=3.0 ; \mathrm{SD}=1.2$ ), fortification of baby's food (mean $=3.1 ; \mathrm{SD}=1.2$ ) and fortification of foo - foo / pounded yam (mean = $3.1 ; \mathrm{SD}=1.3$ ). The low standard deviation (SD) indicated the closeness of the technologies or observations to the respective mean. The implication of this finding is that less than half of 
the technologies meant for sweet potato production, processing and utilization were only used by the farmers and consumers. The result is low output and probably high wastage of the product. According to Ezeano (2006), the low usage of sweet potato technologies by both farmers and consumers were attributable to the newness of the crop, its technologies, poor knowledge of the use of the technologies, lack of finance to purchase the inputs and low extension agent-farmer / consumer ratio predominant in the study area. He further stated that the success in the transfer of technical information and the over all effectiveness of agricultural development programme depends on the availability of inputs associated with the technologies and the expertise in the use of these technologies. Asiegbu (1990) observed that the poor knowledge in the use of certain input and the fear of their side effects has made many farmers scared of using them. He further stated that most farmers in Nigeria do not use fertilizer essentially due to scarcity and high cost, and the small percentage of farmers that use them tend to employ too little per unit area of land.

Table 2: Distribution of respondents according to the extent of use of indigenous and improved sweet potato technologies

Technologies for farmers $(n=144)$

mean standard deviation (SD)

Organic fertilizer application

$4.1 *(.11) \quad 0.8$

Inorganic fertilizer application

$4.0 *(0.12) \quad 0.9$

Correct length of vine cutting

$3.8 *(0.15) \quad 1.3$

(2-5nodes)

Correct spacing (30-50cm apart)

Earthening up

$3.8 *(0.16)$

1.3

Cutting off the vine from the

base at Maturity to prevent boring

$3.7 *(0.18)$

1.3

attack by weevils

Rolling and tying of vine at

the base to increase tubers size

$3.7 *(0.18)$

1.4

Harvesting of tubers in bit and detopping

to induce more tuber production

Use of insecticide / fungicide

Use of herbicide (weed control)

\section{Tractors}

Use of Oxens

Use of sprouts

Use of seeds /leaf buds

Strage in pits

Use of compatible intercrop

Stand geometry (stand ered)

Technologies for consumers $(n=72)$

Processing into:

Flour

Chips

Snacks /fried chips

Starch

Starch to make noodles

Alcohol

Utilization in the production of:

Chindim sfrithers

Buns, doughnut, strips, "akara"

$3.6 *(0.19) \quad 1.4$

$3.6 *(0.17) \quad 1.4$

$2.3(0.18) \quad 1.4$

$2.1(0.16) \quad 1.3$

$1.7(0.10) \quad 1.1$

$1.2(0.10) \quad 1.1$

$2.4(0.13) \quad 1.8$

$2.3(0.12) \quad 1.3$

$2.8(0.13)$

$2.2(0.13) \quad 1.3$

$2.9(0.19) \quad 1.6$

$3.1 *(0.16) \quad 1.3$

$3.1 *(0.19) \quad 1.6$

$3.7 *(0.17) \quad 1.4$

$1.0(0.10) \quad 0.8$

$1.1(0.11) \quad 0.7$

$1.0(0.10) \quad 0.8$

$1.0(0.10) \quad 1.2$
$1.1(0.10) \quad 0.6$ 
Bread, Queen cake, croquette

Beverages (Kunu, Burukutu)

Livestock feed

Syoup, aulture media

Fortification of baby's food

Fortification of foo-foo / pounded yam

$\begin{array}{ll}1.1(0.10) & 0.8 \\ 3.0 *(0.12) & 1.2 \\ 1.8(0.12) & 1.0 \\ 1.2(0.10) & 0.8 \\ 3.1 *(0.15) & 1.2 \\ 3.1 *(0.16) & 1.3\end{array}$

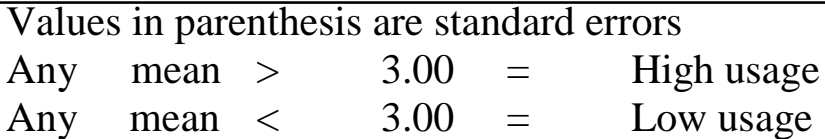

\section{CONCLUSION}

This study examined the technologies used in sweet potato production and utilization among households in southeastern Nigeria. It observed that majority (92.4\%) of the sweet potato farmers used correct spacing of $(30-50 \mathrm{~cm}$ apart $)$ and earthening up in the production of sweet potato while $90.3 \%$ of the farmers used cutting - off the vine from the base at maturity to prevent boring attack by weevils in their production. The sweet potato technologies used by consumers included use of sweet potato products in the fortification of baby's food, fortification of foo-foo / pounded yam, sweetening of local beverages like "Kunu and Burukutu”.

Among these technologies, the following sweet potato technologies were highly used by the farmers; organic fertilizer, inorganic fertilizer, correct length of vine cuttings (2-5 nodes) and correct spacing (30-50 cm apart). The technologies highly used by consumers included; processing of sweet potato products into flour, dried chips, snacks /fried chips, utilization of the flour in sweetening local beverages like (Kunu and Burukutu), fortification of baby's food, and fortification of foo-foo / pounded yam.

\section{RECOMMENDATIONS}

In the light of the major findings of this study, the following recommendations were made to enhance the production, consumption and utilization of sweet potato in southeastern Nigeria. The sweet potato technologies that are user friendly should be developed by the mandate research institutes and passed on to state Agricultural Development Programmes (ADPs) for on ward transmission to end - users by their extension agents. The Women - in Agriculture Programme (WIA) of the state level ADPs are strongly recommended to facilitate campaign on promotion of processing and utilization of sweet potato technologies among Woman and multipurpose cooperatives and agro-allied industrials to reduce post harvest wastes.

\section{REFERENCES}

Agricultural News series (1981)- National Root crops Research Institute Umudike Vol .5.3-4 Asiegbu, J.E. (1990). Crop resource and management in national development. In Ikeme.

A.I. (ed). The challenges of Agriculture in National Development. Faculty of Agriculture, University of Nigeria, Nsukka. Enugu. Optimal Publishers: 198 - 280.

Bashaasha, B. and R.O. Mwanga (1992). Sweet potato: A source of income for low-income rural families in Uganda. In: scott G., P.I. ferguson, and J.E. Herrera. (eds) Product Development for Roots and Tuber crops Vol.lll Africa. Proceedings of the workshop on Processing Marketing and Utilization of Roots and Tuber

Crops in Africa, held October 25 - November 2, 1991 at the International Institute of Tropical Agriculture (IITA), Ibadan, Nigeria by (CIP) International sweet potato Centre, Lima, peru $56-72$ 
Ezeano, C.I (2006). Trends in Sweet potato Production Utilization and Marketing among households in Southeastern Nigeria Ph.D Thesis Department of Agricultural Extension, University of Nigeria Nsukka.

FAOSTAT (1997). Statistics Database (on-line) Accessed, June - Available HTTP: http:// apps.fao.org.

FAO (1989-2001). Nigeria food Balance sheet. Basic Data Branch, Statistics Division FAO, Viole delle, Terme di Caro Calla 00100 Rome Italy.

National Root crops Research Institute (NRCI) (1981). Sweet potato storage by use of Sawdust Research Bulletin P.30

Nnawuchi, P.C., C.N Ubbaonu, S.O. Ezinwoke and O.N, Eke Okoro (2002). On - farm Evaluation of the Acceptability Of High Rotio (40\% and 50\%) sweet potato / wheat flour Compositability in Bakery Products, Buns, chin-chin and Doughnut in Imo State In: Udeaolor A, T.O. Ezulike and J. Aham (eds.) proceedings of the $16^{\text {th }}$ Annual Zonal Research Extension, Farmer input Linkage system. (REFILs). Workshop southeast /south zone of Nigeria. $19^{\text {th }}-23^{\text {rd }}$ November, 2001 pp $113-119$.

Scott, G.J and L. Maldonado (1999). Sweet potato facts A Compendium of key Figures and Analysis for 30 Important sweet potato producing countries (CIP.) Lima, Peru 142 148.

Talekar, N.S. (1987). Influence of cultural pest management Technology on the infestation of sweet potato weevil. Insect sci Applic 8: 815 - 817. In: Obinne, C.P.O, B.A,

Kanu and J.C Umeh, (eds). Indigenous knowledge and sustainable Agricultural development in Nigeria Proceedings of the National conference on Indigenous knowledge and development: $34-45$.

Tewe, O.O, F.E., Ojeniyi and O.A Abu (2003). Sweet Potato Production, utilization, and Marketing in Nigeria. Social Science Department, International Sweet potato Centre (CIP), Lima, peru, Database (on-line). Accessed. March 2003 Available. June 2005. HTTP: http:// www.eseap.cipotato-org/MFESEAP/F/-Libary/spin Nigeria pdf. 